\title{
DASEIN A JEHO MOŽNOSTI
}

Asi nejpodrobnější výklad sémantické historie slova Dasein v současnosti poskytuje heslo „Dasein/Existenz“ v mezinárodním lexikonu „nepřeložitelných výrazů“, jehož hlavní editorkou je Barbara Cassinová. ${ }^{1}$ Heslo, jež vyhotovil Pascal David, zachovává schéma, které máme v obecném povědomí: Kant „vzal a poněmčil“ latinské existentia; Heidegger vzal existující výraz Dasein - který doslova znamená „být tu“a vtiskl mu nový význam.

Důsledným využitím současných databází lze tento obrázek přinejmenším zproblematizovat. ${ }^{2}$

Substantivní výraz Dasein se objevuje v 17. století; jde o běžný výraz s významem ,přítomnost“", totiž přítomnost jedince v nějaké společnosti, u nějaké události či na nějakém místě, ale též (později) například přítomnost prvku ve sloučenině. Nejstarší dohledatelný výskyt je z roku 1666: „Tato kaple byla doposud zazděná,“ píše se v cestopisu G. Ch. von Neitzschitze (v témže žánru bychom našli mnoho dalších ukázek), ,a až ted' v mé př́tomnosti (bey meinem Daseyn) byl vchod znovu probourán. “ Už bratři Grimmové ve svém slovníku píšou, že tento úzus ochabuje; přesto přetrval (coby vzácný, ne však archaický) dodnes.

V průběhu 18. století se pak ujímá významové rozšíření na ,život v celém jeho rozsahu, jsoucnost, existenci, výskyt věcí" (jak formulují Grimmové). Pro život jako takový užívá výrazu Daseyn J. Ch. Gottsched v poémě vydané roku 1730; fiktivní životem znechucený stařec tu prohlašuje, že je na světě nadarmo (Mein Daseyn ist umsonst). Týž Gottsched poskytuje shodou okolností první dohledatelný výskyt vyhraněně filosofického užití pro existenci jednotlivého předmětu, a to v pojednání Erste Gründe der gesammten Weltweisheit z roku 1733; výraz Daseyn však má již v tomto prvním vydání mnohokrát reeditovaného spisu i vlastní heslo v rejstř́ku, což lze považovat za indicii, že jde o etablovaný termín. Jako rovnomocné synonymum přitom Gottsched použivá vazbu wirklich verhanden (verhanden je v dané době užívaná varianta

1 B. Cassin (vyd.), Vocabulaire européen des philosophies: dictionnaire des intraduisibles, Paris 2004. K dispozici jsem měl anglickou verzi Dictionary of Untranslatables: A Philosophical Lexicon, Princeton 2014, zde viz str. 195-199.

2 U hesel v jazykovém slovníku je standardní neuvádět přesné odkazy; pro úsporu místa tak činíme i zde. 
vorhanden) a mluví o tom, že Daseyn vykazuje ta možnost, která se naplní (erfüllet werden) a uskuteční (zu Stande kommen); souhrnný závěr pak zní: Die Wirklichkeit also, oder das Daseyn eines Dinges ist die Erfüllung seiner Möglichkeit (důraz v originále). Jako latinské ekvivalenty jsou na okraji stránky uvedeny výrazy existentia a actualitas a v následujícím výkladovém paragrafu esse.

Nedlouho poté dochází k dalšímu posunu, když se probíraný výraz objevuje s neurčitým členem. V roce 1754 tento úzus nacházíme v gramatice spisovné němčiny Samuela Lenze: předložkové vazby s určitým pádem jsou podmíněny např́iklad tím, že daná předložka „označuje výskyt (ein Daseyn), přítomnost (eine Gegenwart), pohyb nebo zjevné jednáni'“. V roce 1756 se týž úzus opakovaně objevuje v německém překladu Berkeleyho Tří dialogů a Collierova Clavis universalis. Německému „wenn es auch ein Daseyn hätte“ přitom u Colliera odpovídají slova ,if it were in being“. Berkeleyho Tři dialogy jsou překládány z francouzštiny a výrazu ein Daseyn odpovídají např́klad výrazy être či subsistance.

Kant tedy ve spise Der einzig mögliche Beweisgrund zu einer Demonstration des Daseins Gottes (1762-1763) plně využívá možností, které mu dobová němčina poskytuje, avšak není jazykovým inovátorem. Výrazy Dasein a Existenz používá jako synonyma, nevidím ale důvody k tvrzení, že by německý výraz byl významově formován latinským, možná spíše naopak: Kant v úvodní kapitole „Vom Dasein überhaupt“ zdůrazňuje, že Dasein je jednoduchá představa, nespjatá se zvláštní naukou, a možná právě proto filosof užívá téhož výrazu i v dalších nadpisech. V nauce o kategoriích z Kritiky čistého rozumu se Dasein, jak známo, použivá synonymně s Wirklichkeit.

K definičnímu vyhranění ale nedochází jen u filosofů. V roce 1779 píše J. H. Jung-Stilling ve spise Versuch einer Grundlehre sämmtlicher Kameralwissenschaften: „Bytím (existencí) člověka nemíním pouhý jeho život, ale celou tkáň jeho života, celý okruh jeho působení“ (Unter dem Daseyn [Existenz] des Menschen verstehe ich nicht nur das blose Leben desselben, sondern auch sein Weben, wie er lebt, oder seinen ganzen Wirkungskreis); pro holý život či základní potřeby je naopak zaveden termín das blose (sic) Daseyn .

Hegelovu letmou lexikální poznámku z Velké logiky - výraz Dasein prý „etymologicky vzato“ znamená „bytí na určitém místě“ (etymologisch genommen: Sein an einem gewissen Orte) - dlužno brát se zrnkem soli. Podstatnější informaci i o Hegelově vlastním jazykovém cítění nám naopak skýtá fakt, že Dasein u něj označuje „určité“, „konkrétní“ bytí. 
Dasein ve smyslu ,život“ se v průběhu 19. století osamostatňuje, tj. dané slovo může zmíněný význam nést i mimo vazby typu unser $D a$ sein či menschliches Dasein, které prŕslušnou dimenzi specifikují. Spis z roku 1886 o pojetí smyslu života v biblické knize Kazatel tak nese název Koheleth's Untersuchung über den Wert des Daseins a manuál křest'anské dogmatiky z pera A. E. Biedermanna, vydaný roku 1869, může obsahovat následující pasáž: „Das Sein des endlichen Daseins, das in dessen positivem Da-sein als räumlichem nicht da ist, und doch als Grund seinem Dasein immanent sein muss, ist negativ in ihm da, als der Zeitprocess des räumlich Daseienden“ (důraz v originále; orientační překlad: „Bytí konečného života - bytí, jež není obsaženo v jeho pozitivním bytí-tu coby prostorovém, a přesto musí být v jeho žití imanentní coby důvod v něm jest negativně, coby časové dění toho, co jest a žije v prostoru“").

Když tedy Thormayerův filosofický slovník ve třetím vydání z roku 1922 uvádí pro termín Dasein jediné objasnění, a to „skutečný výskyt v protikladu k myšlenému bytí", lze to přijmout jako charakteristiku dominantního úzu v prostředí akademické filosofie; rozhodně se tím ale nevyčerpává celé významové spektrum slova - a to ani s ohledem na akademické prostředí. Heidegger oživuje významové souvislosti $\mathrm{s}$ dlouhou historií, které byly přítomny v mluvené, literární i odborné němčině.

Jak Dasein překládat? Patočkou navržený „,pobyt“, zachovaný překladateli Bytí a času, se ve světle uvedených skutečností jeví jako velmi dobrá, snad i optimální volba: německý výraz se také vyvíjel od dočasného pobývání na určitém místě či v určité společnosti k celoživotnímu „pobytu“ každého člověka na světě. Obsahově mírně výhodnější je ,pobývání“, zbavené konotace intervalu stráveného mimo domov; sdílí ale negativní rys mnoha dalších alternativ, totiž nesklonnost.

Pokud bychom chtěli (s odvoláním na Heideggerovo zdůraznění momentu Da v Bytí a čase) zachovat morfologickou kompozici německého vzoru, dlužno preferovat „tu“ před „zde“ a „tubytí“ před „bytí tu“. Německé $d a$ v Dasein neoznačuje určité fixní místo, nýbrž volný a volně expandovatelný okruh toho, co je přítomno, co je relevantní a zjevné; tomu v češtině lépe odpovídá příslovce „tu“, nikoli ,zde“. „Zde“ zpravidla evokuje ukázání prstem, bod či vymezenou oblast v prostoru; školní a vojenské „Zde!““, jež vyjadřuje přítomnost, je v tomto směru výjimkou. Výraz „tu“ naopak přirozeně spojujeme především s idiomy „tak už jsem tu“ (tj. spolu s vámi), „tu to máme“ (po ruce) nebo „ach, není tu, není“ (tj. je pryč, sešlo ze světa). Jinak řečeno: české „zde“ nese výhradně 
prostorový význam, zatímco české „,u““, stejně jako německé $d a$, může mít i význam časový; povel „Počkej tu!“, vyjadřující přesné místní určení, je v tomto směru výjimkou. Právě tuto výjimku ale může evokovat substantivizovaná vazba „bytí tu“, zatímco tvar „tubytí“ je významově přesnější a navíc originálu odpovídá morfologicky.

Pokud bychom chtěli uvažovat o nové překladové variantě, nabízí se české slovo „byt“, jehož škála významů sahá od jednotlivé bytosti přes pobyt a místo k pobytu po život a bytí jako takové. Staročeská skladba Tkadleček obsahuje slova: „vše, což živost aneb byt má neb kde jest“, Chelčický píše v Postile o Kristu: „Vešken byt putovánie jeho zde pracovitý byl.“ Jungmannův slovník uvádí „byt“ jako jeden z ekvivalentů německého Daseyn. Ještě za první republiky se slovo „byt“ běžně užívá pro způsob života daného národa nebo společenské vrstvy (Josef Pekař či Josef Čapek píši o bytu rolníků a sedláků), míní se tedy určitá modalita existence; vedle toho samozřejmě následný sémantický vývoj akcentuje prostorový aspekt. Výraz „byt“ tedy zachovává všechny významové složky výrazu ,pobyt“, přitom ale postrádá nepatřičné konotace dočasného přesunu jinam; akcentuje naopak prostorovou dimenzi a modální aspekt; shodně s německým Dasein konotuje celý život; a oproti „tubytí“ je skloňovatelný.

Martin Pokorný 